\title{
Implementing a multimodal online program for very young learners of Russian: Educators' perspective
}

\author{
Albina Kayumova and Gulnara Sadykova \\ Department of Romance-Germanic Philology, Institute of Philology and Intercultural Communication, Kazan \\ (Volga Region) Federal University, 2, Tatarstan Street, Kazan, postcode code 420021, Russia
}

\begin{abstract}
CALL and MALL learning programs have been introduced by preschool teachers into their language classrooms (Sadykova, Kayumova, Khalitova, \& Gimaletdinova, 2017; Segers \& Verhoeven, 2003), despite reports saying that some of these programs have little educational value (Kazanci \& Okan, 2009). This exploratory mixed-methods study aims at examining how Russian language kindergarten and preschool teachers integrate resources of a Russian language online school Live Fairytales ${ }^{\mathrm{TM}}$ (Zhivye skazki, 2017) and what design elements of this multimodal digital resource they find conducive or impediment to successful language acquisition by young learners. The data come from the reports of six teachers and survey responses of 18 educators who described and reflected on their experiences integrating resources of the Russian language online school. The data show that teachers made productive use of the digital resource by utilizing its multimodal presentation of the content, integrating interactive activities mostly in a whole-class format, and creating an engaging and enjoyable learning environment of play. Visual representation of material was reported to be the most valuable and necessary for accompanying audio input, introducing or practicing vocabulary, supporting listening comprehension, and overall motivating very young learners to stay on task. This study extends our understanding of what early childhood educators expect from quality digital resources and how they integrate them into educational programs that support language acquisition of bilingual and multilingual preschool children.
\end{abstract}

Keywords: Digital resources; early childhood education; language learning software; multimodality; technology-assisted language learning

First Received:

1 October 2018

Final Proof Received: 27 May 2019

\section{Revised:}

28 March 2019

\section{Accepted:}

25 April 2019

Published:

31 May 2019

How to cite (in APA style):

Kayumova, A., \& Sadykova, G. (2019). Implementing a multimodal online program for very young learners of Russian: Educators' perspective. Indonesian Journal of Applied Linguistics, 9, 1-13. doi: 10.17509/ijal.v9i1.13323

\section{INTRODUCTION}

With the arrival, growth, and development of personal desktop computers and later mobile technologies, there has been a significant shift in methods of teaching and learning languages. The number of computer-assisted language learning (CALL) and mobile-assisted language learning (MALL) software has skyrocketed, including programs for very young second/foreign language learners.

However, to date little do we know about the use and effectiveness of the computer and mobile applications for young language learners. According to Grgurović, Chapelle and Shelley's (2013) meta-analysis of empirical research on the effectiveness of CALL from 1970 to 2006, the vast majority of studies have focused on a higher education setting, while primary, secondary, private language schools or adult literacy settings appeared to be underrepresented in CALL research. None of the articles presented in the study focused on using CALL technologies in preschool institutions. The same holds true for trends in MALL: Burston's (2015) meta-analysis of learning outcomes showed that participants of studies conducted up to 2012 were nearly equally divided between adult learners and school students. While more current studies have started including very young learners into their research

\footnotetext{
* Corresponding Author

Email: alb1980@yandex.ru
} 
interests (Meyer, 2013; Sadykova et al., 2017), Generation Z (also known as iGeneration or PostMillennials) is still underrepresented in CALL and MALL research. Such a lapse in research calls for action, especially considering the fact that in technology-rich countries, this target audience has become very active users of computer and mobile apps (OfCom, 2017).

While CALL research focusing on very young children is still scarce, one could identify four major topics of research interest: effects of CALL/MALL technologies, platform design features, educational value of software, and attitudes of parents and educators towards CALL/MALL technologies.

Studies analyzing the effects of CALL/MALL technologies came from, among others, Segers and Verhoeven $(2003,2005)$ who investigated the extent to which the use of technology facilitates the acquisition of language in terms of developing pre-reading and prewriting language skills, i.e., vocabulary acquisition (Segers \& Verhoeven, 2003) and phonological awareness (Segers \& Verhoeven, 2005). The two studies were undertaken in kindergartens in the Netherlands and involved both native and immigrant children. Positive effects of the computer training were found on vocabulary acquisition, rhyming, and grapheme knowledge.

Some studies investigating the effects of CALL in classrooms --conducted, however, at school or university levels -- suggest that multimodal presentation of information is ideal for language education (Cummins, 2008; Meskill, 2002) and may be used to support bilingualism and biliteracies (Lohe \& Elsner, 2014; Meskill \& Mossop, 2000). The multimodal presentation of information through the combination of text, sound, and visuals may amplify target content (Meskill, 2007) and help young learners develop new literacies related to the manipulation of sound, visuals, and text present in (CALL) technologies (Meskill, Mossop \& Bates, 1999).

Other studies on the effects of CALL have reported that multimodal online environments may change patterns of communication in the learning process. Such interaction changes are most evident when language learning involves distance communication as in video conferencing (Hampel \& Stickler, 2012), but could still nonetheless impact young learners' direct interaction with content and teacher in traditional face-to-face classrooms as indicated by Meskill (2007).

Meanwhile, studies on platform design features were conducted by Meyer (2013) in her study of gamebased language learning for preschool children. She took a design perspective and examined the features of a platform for learning English in a preschool setting. She discussed internal and external feedback features of the platform and emphasized the importance of positive feedback and guidance for supporting students' engagement and helping a child to see how she/he is doing. She also found that the platform external features require the active presence of an adult guide.

Regarding research on the educational value of software, Kazanci and Okan (2009) critically evaluated educational software programs for children. Employing an assessment chart, they examined six programs to examine whether the elements of entertainment and education are well balanced in software for young children. They found "excessive, pointless, and flashy use of entertainment elements while cognitive tools that can engage students in learning are completely missing" (p. 36).

Finally, studies surveying parents' and preschool educators' attitude towards CALL for very young learners (Sadykova et al., 2017) showed that the vast majority of respondents were CALL supporters; however, preschool teachers admitted that they needed more formal training in using CALL with very young learners. A study published by the same group of researchers a year earlier (Sadykova, Gimaletdinova, Khalitova, \& Kayumova, 2016) revealed that most parents of young EFL learners did not see an educational value of mobile language learning applications, while preschool educators were very enthusiastic about MALL applications for their young learners.

Thus, as indicated by these studies, there are differing views on the educational value of CALL and MALL resources for very young language learners. Unfortunately, there is very little information on how educators use these resources in the classroom and how they evaluate the educational value of the design features of the programs they use. Little do we know about early childhood educators' perspectives over the CALL software for very young children, particularly their views on multimodal features that make this software educationally valuable.

This exploratory mixed-methods study is conducted as an attempt to address these gaps in the research of CALL for young language learners. In particular, this study is aimed at examining how educators integrate digital learning objects, specifically resources of a Russian language online school Live Fairytales $^{\mathrm{TM}}$ into the curriculum of very young language learners. It also explores design elements of this multimodal digital resource that educators find conducive or impediment to successful language acquisition by 3-5-year-old learners.

\section{METHOD \\ Context of the study: Russian language online school Live Fairytales ${ }^{\mathrm{TM}}$}

This study is based on data that was collected from educators who integrated resources of a Russian language online school for young learners Live Fairytales $^{\mathrm{TM}}$ accessible at https://skazki.pushkininstitute.ru/

Live Fairytales ${ }^{\mathrm{TM}}$ is a product of a federallyfunded project created in $2016-2017$ by a project team of Kazan Federal University (Russian Federation) under 
the auspices of the Ministry of Education and Science of the Russian Federation. The development and integration of the online school were done as a part of a federal program Russian Language 2016-2020 aimed at expanding the range of quality open-access online resources for young Russian learners living in multiethnic areas of Russia and abroad. The school was developed by a group of language and literature experts, instructional designers, second language acquisition professionals, and IT specialists, including both of the researchers of this study.

The school includes two levels: first aimed at children of 3-4 years old and second for children of 4-5 years old (Figure 1). Each level is comprised of 8 modules built around a single topic, such as "clothes," "family," or "Victory Day." A module generally includes: 1) pre-text activities that activate and introduce new vocabulary, 2) an illustrated short version of a story (mostly written in the genre of a fairytale with the exception of one module) with an audio recording (choice of male or female voices), 3) two post-listening activities, 4) an illustrated long version of the same story (fairytale), and 5) two post-listening activities.

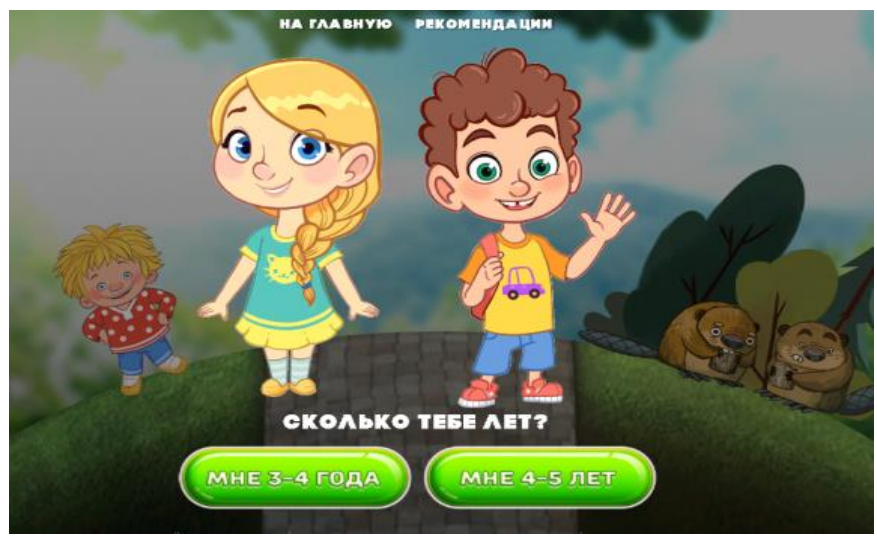

Figure 1. Screenshot of Live Fairytales ${ }^{\mathrm{TM}}$ homepage

The online school also includes a scoring feature; the children receive gems for each completed activity. The tasks are introduced by the main characters - a 3 year-old girl Masha in Level 1 and a 4-year-old boy
Misha in Level 2, as well as by two fairytale creatures the dragon Zmej Gorynych and a gnome-like little man Domovoj, the two being derived from traditional Russian folktales (Figure 2).

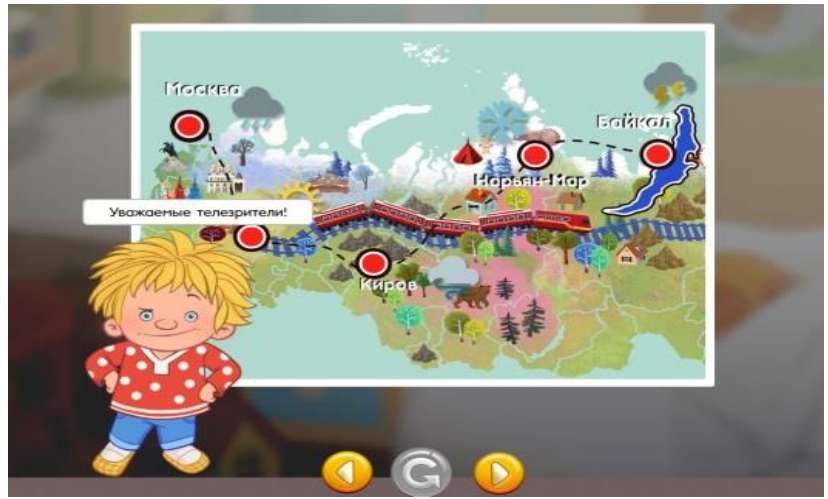

Figure 2. Screenshot of a scene from Live Fairytales ${ }^{\mathrm{TM}}$ with Domovoj

\section{Study design}

The participants of the study were educators working in bi- or multilingual state-funded or private kindergartens in one of the multiethnic regions of the Russian Federation - in the Republic of Tatarstan. The educators were Russian language teachers or regular kindergarten/preschool teachers who worked with children whose native (home) language is predominantly Tatar.

\section{Study design: Stage 1}

The research was conducted in two stages. On the first stage, five kindergartens were selected based on their language curriculum (bi- or multilingual) and willingness to be involved into the integration of a Russian online language school for children Live Fairytales $^{\mathrm{TM}}$. The recruitment of sites was done through the Ministry of Education of the Republic of Tatarstan who agreed to send an invitation letter to kindergartens situated in areas with predominantly Tatar language environment. One site, a private multilingual kindergarten in a large city, was self-selected based on the interest of their administration and long-standing partnership with the university where the research project was carried out.

In winter and spring of 2016, the project team 
started the formative evaluation of the first two pilot modules of Live Fairytales ${ }^{\mathrm{TM}}$. At this stage, five kindergartens/preschools were involved in the integration of the modules into an existing language curriculum. The process involved 6 educators who worked in 6 different kindergarten groups. Overall, 51 children participated in 10-20-minute Russian language lessons that integrated Live Fairytales ${ }^{\mathrm{TM}}$ materials; these were 15 three-year-olds, 17 four-year-olds, and 19 five-year-olds. Educators were not guided or pre-taught by the project team members on how to integrate Live Fairytales $^{\mathrm{TM}}$ resources into their existing curriculum.

All 6 kindergarten teachers received a report template with five items to be filled after their use of two pilot modules of Live Fairytales ${ }^{\mathrm{TM}}$. The teachers were asked to provide information on the demographics of the group of children, the date and time of a lesson with Live Fairytales ${ }^{\mathrm{TM}}$, a detailed description of the lesson procedures, their analysis of lessons and recommendations for online school designers.

The reports were collected and analyzed qualitatively to examine how educators chose to integrate Live Fairytales ${ }^{\mathrm{TM}}$ pilot modules, how they evaluated these modules in terms of their educational potential, and what recommendations for improvement they provided.

\section{Study design: Stage 2}

In May-June 2017 all 16 modules of Live Fairytales ${ }^{\mathrm{TM}}$ were launched in the beta version. At this time the project team sent a new invitation letter to kindergartens of the Tatarstan Republic, as well as to other educational organizations which might be interested in new resources for young Russian language learners. The invitation was sent to the email address of 40 educators and 10 multilingual kindergartens recommended by the Ministry of Education and Science of the Republic of Tatarstan. The same invitation in English and Russian was also forwarded to 9 educational centers outside of Russia; these were centers found on the Internet that offer Russian language programs for children abroad. The invitation letter informed the respondents about Live Fairytales ${ }^{\mathrm{TM}}$, invited them to integrate these resources and complete a Google Docs survey based on their experience of applying the online modules. The anonymous questionnaire consisted of 18 questions, including 15 close-ended, 2 open-ended questions, and a space to provide contact information in case respondents wanted to receive further information about Live Fairytales ${ }^{\mathrm{TM}}$ project.

The questionnaire was completed by 18 respondents. The data collected were analyzed quantitatively and qualitatively. The graphs to illustrate answers to multiple choice questions were created and interpreted. The answers to open-ended questions were examined to reveal recurrent themes.

\section{FINDINGS}

Data collected from reports and questionnaires enabled the researchers to picture the profiles of the study participants. Stage 1 of the research involved 6 kindergarten teachers, including 2 Russian language educators (teachers coming to class for a short period of time to teach Russian) and 4 regular kindergarten teachers who integrated Live Fairytales ${ }^{\text {TM }}$ activities into their everyday curriculum of groups of bi- and multilingual children.

Stage 2, participants' answers revealed that the survey was mostly completed by teachers of the Russian language $(87.5 \%)$ who teach children from 3 to 7 years old. One education consultant $(12.5 \%)$ took part in a survey as well. Children that they worked with could be classified as bilinguals as 66.7 to $77.8 \%$ of them demonstrated Russian language skills expected from native language children of the same age (Figure 3 ).

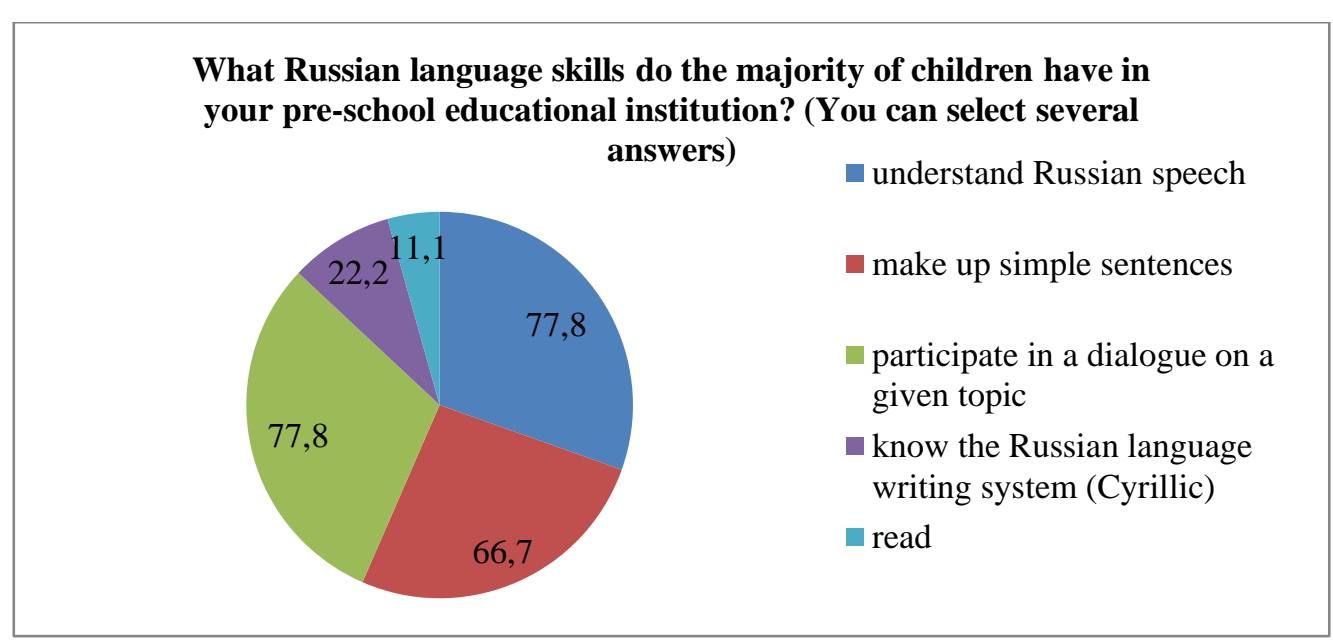

Figure 3. Russian language skills of the majority of children in the kindergarten/preschool (survey responses, \%)

Out of 18 modules of Live Fairytales ${ }^{\mathrm{TM}}$ participants of the study mostly used Module 1 of each level. This was partly due to the fact that on Stage 1 only first modules of each level were designed and launched. The majority of survey respondents $(87.5 \%)$ also worked with Module 1; however, some of the teachers $(25 \%)$ worked with Modules 2-7 and only two teachers (12.5\%) used Module 8 (Figure 4). 


\section{Which module of Live Fairytales did you work with? (You can select several answers)}

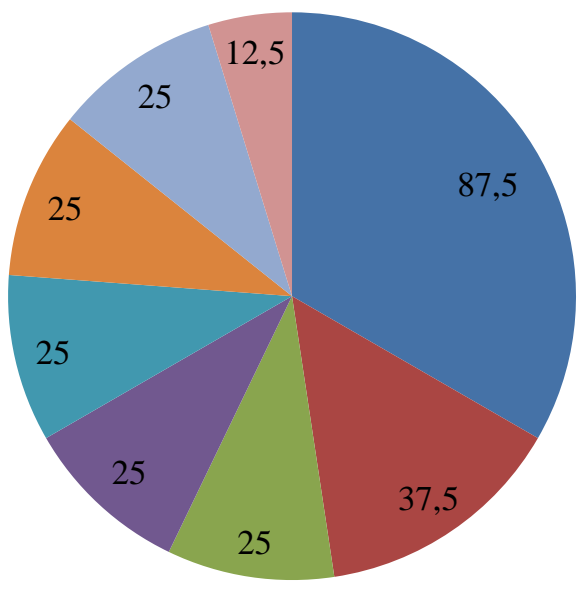

- Module 1

- Module 2

- Module 3

- Module 4

Module 5

- Module 6

Module 7

Module 8

Figure 4. Live Fairytales ${ }^{\mathrm{TM}}$ modules integrated into the curriculum by survey respondents (survey responses, \%)

The reports of the 6 educators collected on the first stage of the research and responses to the questionnaire completed by 18 educators demonstrated the overall high educational value of Live Fairytales ${ }^{\mathrm{TM}}$ for developing skills of young Russian language learners. Five major themes indicated in subsections below were observed and coded recurrently in the data collected.

\section{Modes of integration}

Study participants were not trained or provided with any other means of cueing on how to integrate online activities of Live Fairytales ${ }^{\mathrm{TM}}$. Data, however, showed that modes of integrating online resources were often similar in different sites, which could be due to similar educational contexts of kindergartens and preschools that participated in the study.

A whole class (group) format of learning was most popular among survey respondents: in the majority of sites $(77.8 \%)$ children interacted with Live Fairytales ${ }^{\mathrm{TM}}$ in groups rather than individually. Two teachers $(11.1 \%)$ combined group work and individual work (Figure 5). Six educators who integrated Modules 1 on Stage 1 of the study also reported working with the whole group of children, though some groups included as few as 5, 7 or 8 children, which is typical of private kindergartens but not typical of state-funded early education schools. While educators overwhelmingly selected the group format for working with online resources, this seems to have been done partly due to the necessity to involve all children and the lack of individual computers for each child. One educator who completed the report on Stage 1 of the research stated that to make the best out of working with the online resources, one should work in small groups or individually. Meanwhile, a survey respondent lamented not having time working with children individually.

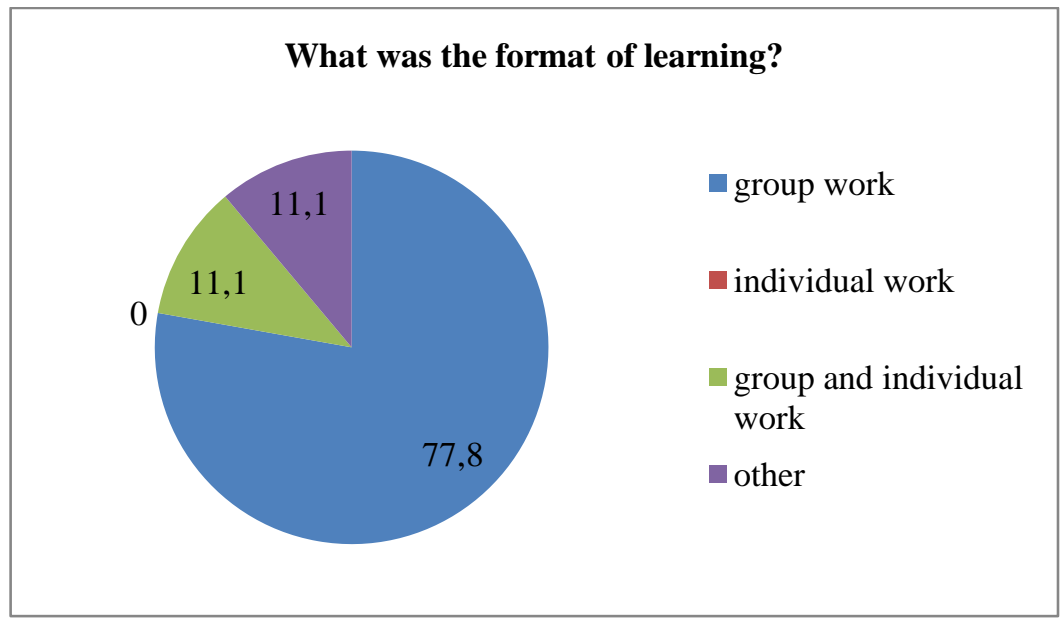

Figure 5. Format of learning when working with Live Fairytales ${ }^{\mathrm{TM}}$ (survey responses, \%)

An interactive whiteboard (smartboard) or a single class computer served as a primary tool to present and work with the online resources. More than half of the teachers $(55.6 \%)$ used an interactive whiteboard to work with Live Fairytales ${ }^{\mathrm{TM}}$, $44.4 \%$ worked with a computer, and $11.1 \%$ of the teachers used an overhead projector. 
Only two teachers $(11.1 \%)$ gave tablets to children to work with the resource (Figure 6). Reports of educators from Stage 1 indicated that at least in two cases the teachers used an interactive board; in one case, a single class computer; three other educators did not report their choice of the device. Thus, non-portable devices were more often used in the classroom, which illustrates a common situation in well-equipped schools in the Republic of Tatarstan: mobile devices or personal computers for each child were not typical for most kindergartens and preschools. The use of a large screen was also more appropriate for the most common format of learning - the whole group.

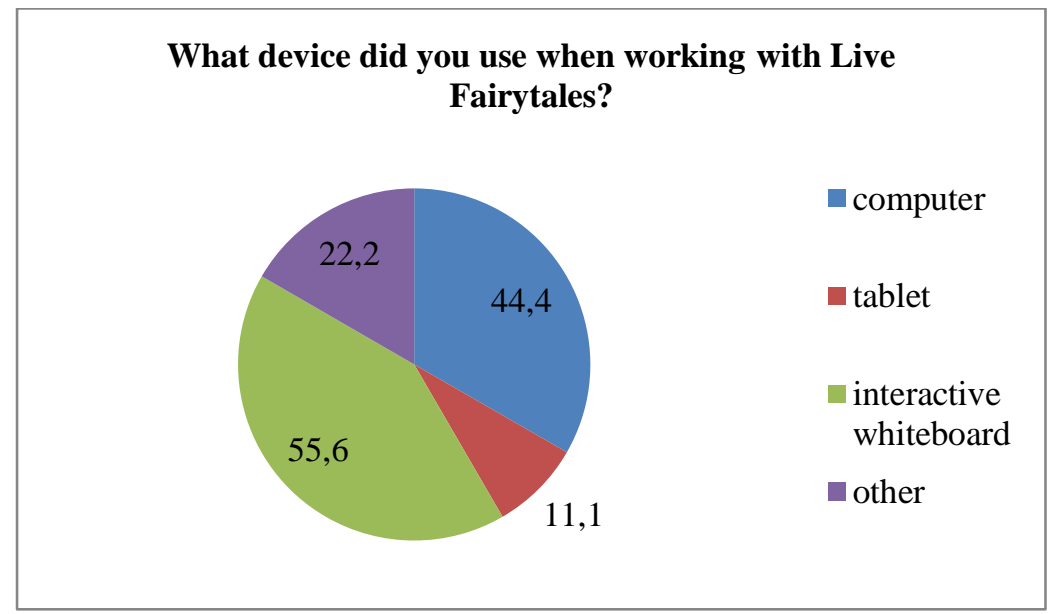

Figure 6. Devices used when working with Live Fairytales ${ }^{\mathrm{TM}}$ (survey responses, \%)

When survey respondents were asked about the time they spent on Live Fairytales ${ }^{\mathrm{TM}}$ activities, more than half of them $(66.7 \%)$ answered that their lessons lasted from 16 to 20 minutes; six teachers (33.3\%) had lessons longer than 20 minutes (Figure 7).

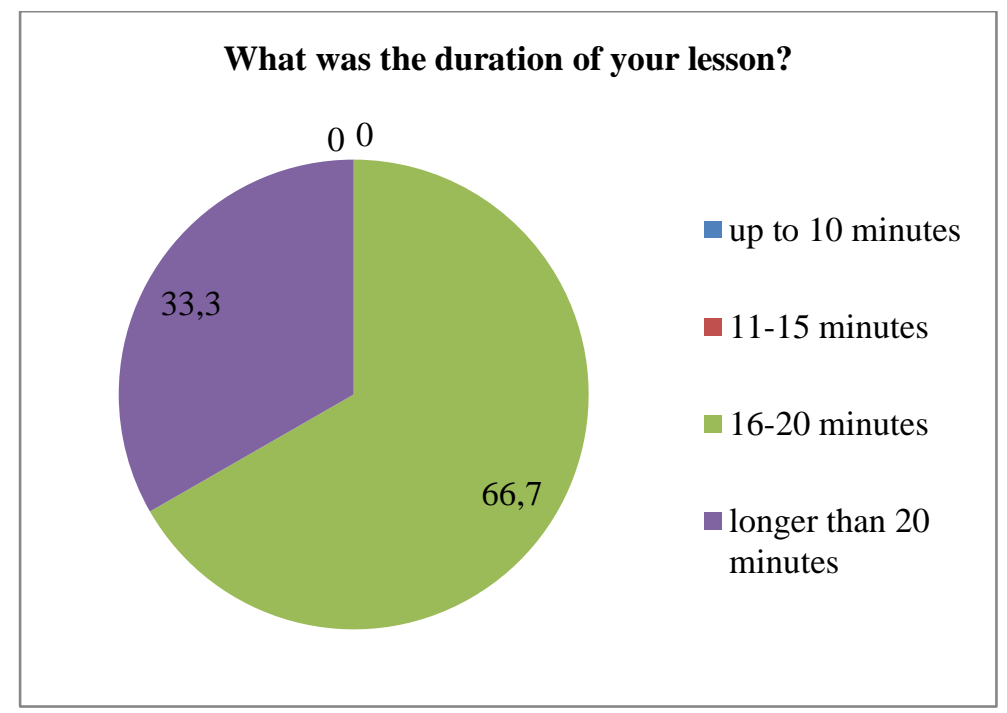

Figure 7. Duration of a lesson when working with Live Fairytales ${ }^{\mathrm{TM}}$ (survey responses, \%)

The reports of educators provided a glimpse of the lesson procedures. The teachers generally followed the structure of a Live Fairytales ${ }^{\mathrm{TM}}$ module, as follows:

Lesson 1. Initial presentation of main characters (a girl Masha in Level 1 and a boy Misha in Level 2) and key vocabulary introduction through interactive games.

Lesson 2. Listening to a short version of a fairytale and completing two interactive tasks.

Lesson 3. Listening to a long version of a fairytale and completing two interactive tasks.
Students sat in a line or a semi-circle in front of a whiteboard, computer screen or an overhead projector and stood up in turns to do interactive tasks on the interactive whiteboard or on the computer.

However, some teachers chose to select only a part of a module for a single lesson. For example, they could use only a vocabulary activity to introduce and/or practice words related to the topic of the module, such as "transport" or "food." Educators reported integrating computer-based activities into traditional tasks. One of the educators described how she asked students to create a dialogue around the topic "transport" they just 
learned. Thus digital resources of Live Fairytales ${ }^{\mathrm{TM}}$ were used as a tutor and well served the purposes of a traditional syllabus.

\section{Students' engagement}

"Screen magic" is a common topic for research studies that demonstrate the power of technologies as a tool for motivation (Liu, Wang \& Tai, 2016; Sylvén \& Sundqvist, 2012). This was evident in the current study, as well. Educators reported active engagement of children with online activities offered by the online Russian language school. In one case, an educator wrote that children were so excited that they asked for repeating the same activities.
Clicking the mouse or touching the screen of a smartboard to do interactive activities seemed to be the most favorite part for most children. Educators reported that children argued over taking turns when manipulating with the digital objects while performing an activity. Moreover, according to the survey responses, for most children the development of their fine and gross motor skills allowed them to do such activities independently: only 4 survey respondents (22.2\%) indicated that just $20 \%$ to $40 \%$ of their children possessed fine and gross motor skills that enabled them to complete the tasks independently, while over one third of the respondents reported that over $80 \%$ of their children possessed such skills (Figure 8).

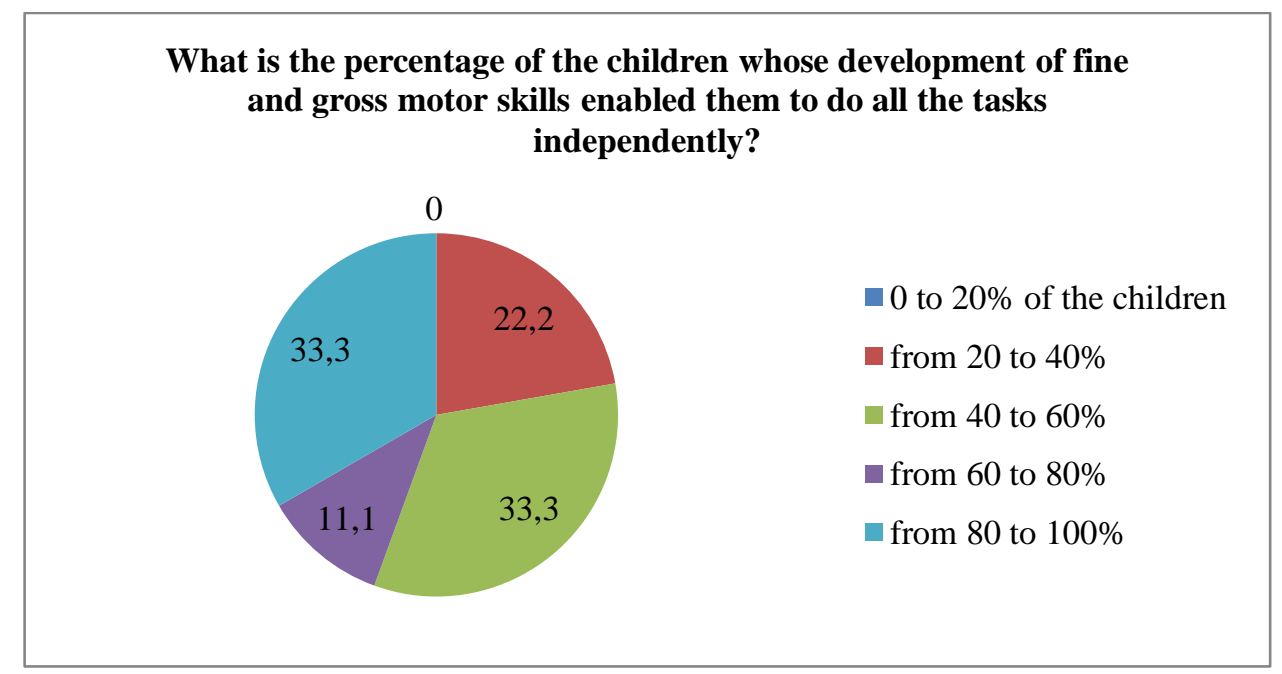

Figure 8 . The percentage of children whose fine and gross motor skills enabled them to perform online activities independently (survey responses, \%)

The level of language difficulty did not seem to be a problem for most kids involved in the classes that integrated Live Fairytales ${ }^{\mathrm{TM}}$ activities. The highest number of survey respondents $(44.4 \%)$ replied that $60 \%$ to $80 \%$ of their young learners had adequate Russian language proficiency to complete tasks independently; for $33.3 \%$ of educators such a level of proficiency was reached by $40-60 \%$ of children and only in 4 cases $(22.2 \%)$ less than half of all students could perform tasks independently due to their Russian language skills. Thus, some groups were of mixed Russian proficiency levels, which might have made children's engagement in whole class activities more problematic. Using individual formats of working with online resources might have been more effective in such cases; CALL and MALL technologies can assist with individualized tracks very well as has been demonstrated numerous times in relevant research (Cappellini, Lewis, \& Rivens Mompean, 2017; Schwienhorst, 2008).

The data demonstrated that sometimes students could lose interest in the topic and get disengaged not because of their low language proficiency level, but due to gaps in the existing knowledge base related to their living environment. In one case the topic "transport" happened to be too difficult for most children because they lived in the countryside and the online module was about city means of transportation. The teacher explained that her group of 4-5-year-olds would study this topic in their native (Tatar) language only in a year, and thus they did not have enough knowledge background to learn city means of transportation in their second language. This case raised the question of synchronizing speech development curricula of two languages that children acquire at the same time - their native (home language) Tatar and second (state) language Russian.

Overall, for most children, Live Fairytales ${ }^{\mathrm{TM}}$ activities matched their motor skills and language proficiency levels. Educators' reports confirmed that their children showed interest in the story plots, liked the main characters, were able to complete most tasks independently, enjoyed "turning pages" of digital storybooks or clicking and dragging pictures in interactive exercises, and were very much excited to receive rewards in the form of gems from the dragon Zmej Gorynych. One teacher also mentioned that students' engagement was evident in the active use of gestures and facial expressions showing surprise. Evoking positive emotions of learners in the language classroom is a recommended technique for lowering the affective filter and enhancing learning outcomes in the classroom with young or adult learners alike. This is in 
line with what is suggested in related previous studies (e.g., Khajavy, MacIntyre, \& Barabadi, 2018; Young, 1991).

However, educators also reported having difficulties engaging all students in the whole class learning format. They stated that those children who were not doing an activity could get noisy and off task, which is typically not just for online large group activities but for traditional classrooms as well (Hunter, 2015, 2016; Rogers \& McPherson, 2014).

Four survey respondents and two educators who completed reports on Stage 1 of the research indicated that their children lost interest while listening to the full (long) version of the story. As mentioned above, each module of Live Fairytales ${ }^{\mathrm{TM}}$ includes two versions of the same story - a short version, being introduced at the beginning of the module, and a long (full) version that comes closest to the end of the module. The problem with the long version of a story was partly later solved when IT specialists added a pause button upon the request of content developers. This enabled educators to manipulate the storyline, making pauses for clarifying the meaning of some words or asking children listening comprehension questions.
It is important to mention here that while in some cases the long version might be considered by some educators as redundant, the content developers' intention was to provide language learners with the option to listen to a more complicated plot and language story. This was done, first, to attend to needs of language learners with different language proficiency levels (including balanced bilinguals, heritage learners and native Russian children who need to enrich their language skills), and second, to build a module that enables the educator to offer the activity, where the "more capable other" (Vygotsky, 1978), e.g., teachers, parents, and older siblings, is a must to complete the task. The introduction of such an online activity that required the active involvement of a teacher, i.e., constant human interruption of the digital story, was ingrained into the concept of Live Fairytales ${ }^{\mathrm{TM}}$, which in many ways was based on the Vygotskian sociocultural ideas. Such concept, however, seemed to require an additional explanation for educators, and appropriate methodological recommendations should have been embedded into the design of the online school.

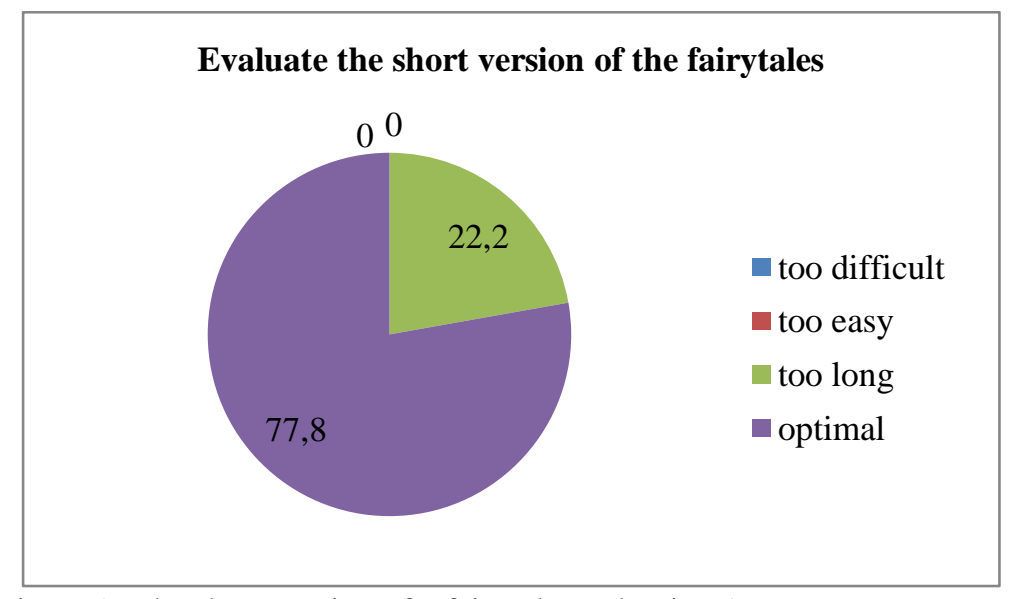

Figure 9. The short version of a fairytale evaluation (survey responses, \%)

\section{Contribution to language skills development}

The research data show that all educators who participated in the study by completing reports or filling questionnaires found online activities of Live Fairytales $^{\mathrm{TM}}$ useful for speech development of their young learners. Teachers made use of the online school resources for developing vocabulary, building "speech etiquette" (a quote from a report) and learning about Russian culture.

While the data collected did not focus on the effectiveness of the online materials for developing language skills per se, they speak for the educators' high appraisal of the short version of the story and of interactive tasks. $77.8 \%$ of survey respondents found the short version of the story optimal for the use in kindergartens and preschools (Figure 9). At the same time, $88.9 \%$ of respondents thought that module activities were effective for the use with young learners (Figure 10). However, just 25\% of educators thought that the long story was optimal and could be effectively used in kindergartens or preschools (Figure 11).

Further research is needed to see if Live Fairytales $^{\mathrm{TM}}$ activities positively affect speech development of young learners of Russian and if and how the full version of the story could be integrated effectively into the curriculum of preschool Russian language learners.

\section{Multimodal presentation of information}

Multimodal presentation of learning material very well suits the needs of language learners (Meskill \& Mossop, 2000), particularly young bilingual children (Cummins, 2008; Sankey, Birch \& Gardiner, 2010). In Live Fairytales $^{\mathrm{TM}}$ the combination of visuals, sounds, and texts, which were created specifically with very young learners in mind, seemed to be very well accepted by the children and educators who participated in the current study. 


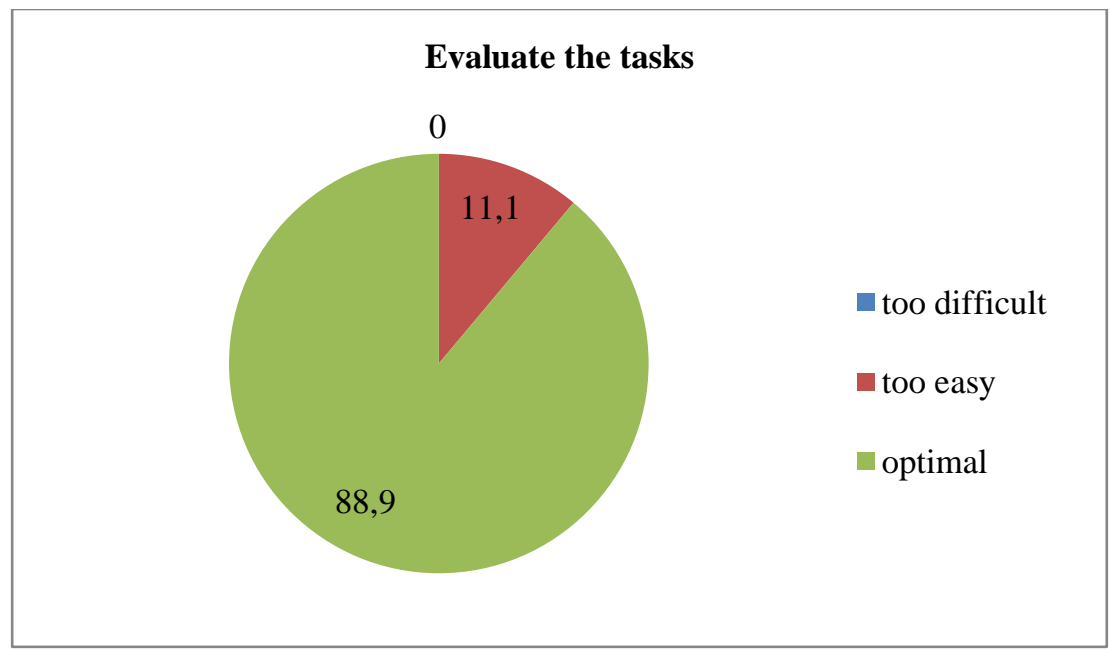

Figure 10. Activities evaluation (survey responses, \%)

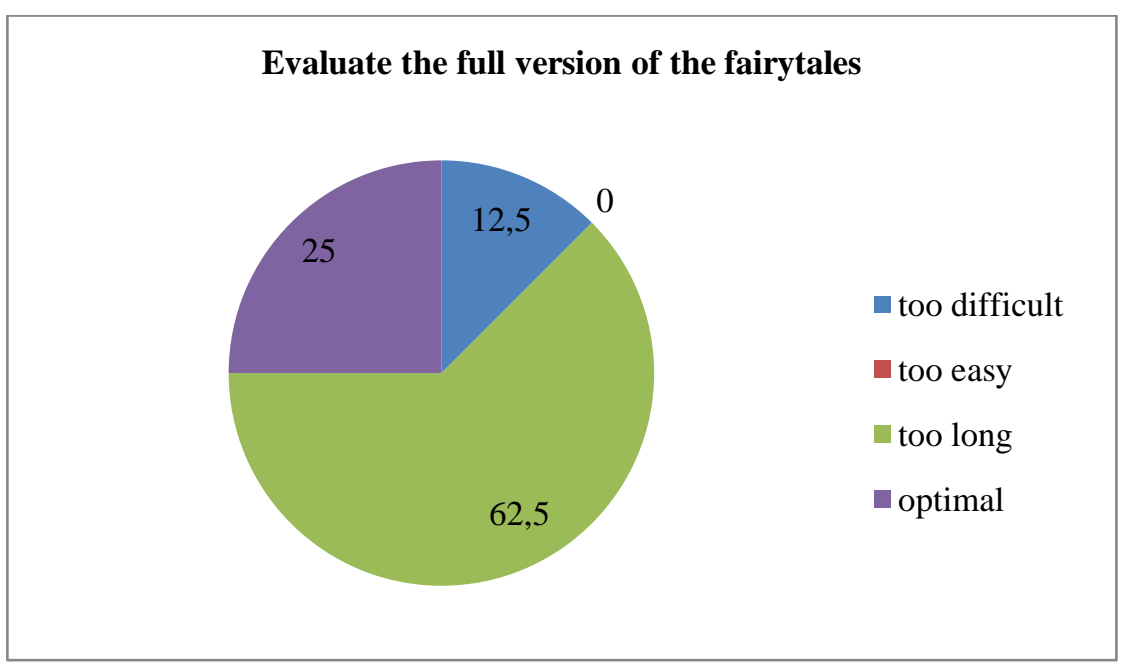

Figure 11. The full version of a fairytale evaluation (survey responses, \%)

The survey asked the respondents to evaluate the graphics and visual effects of the modules. The respondents were either partially satisfied $(66.7 \%)$ or fully satisfied (33.3\%) with the visual content of Live Fairytales $^{\mathrm{TM}}$ (Figure 12).
When asked about their satisfaction with the audio content, the number of those who were partially satisfied increased to $77.8 \%$, while $22.2 \%$ of the respondents said that they were fully satisfied with the audio content (Figure 13).

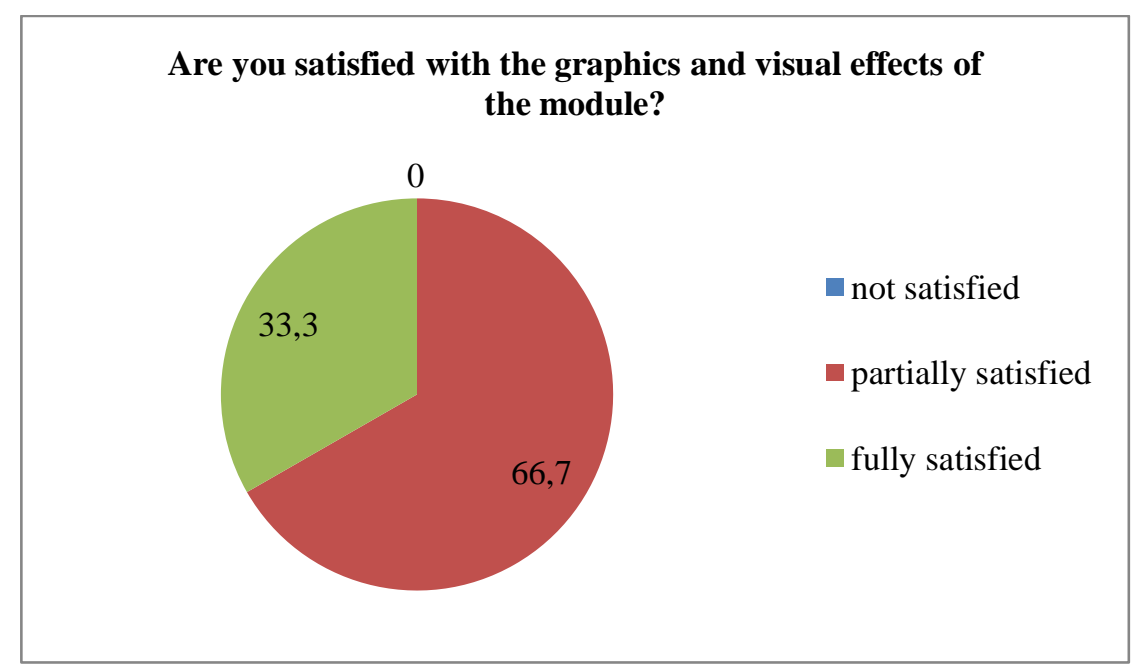

Figure 12. Satisfaction with the graphics and visual effects (survey responses, \%) 


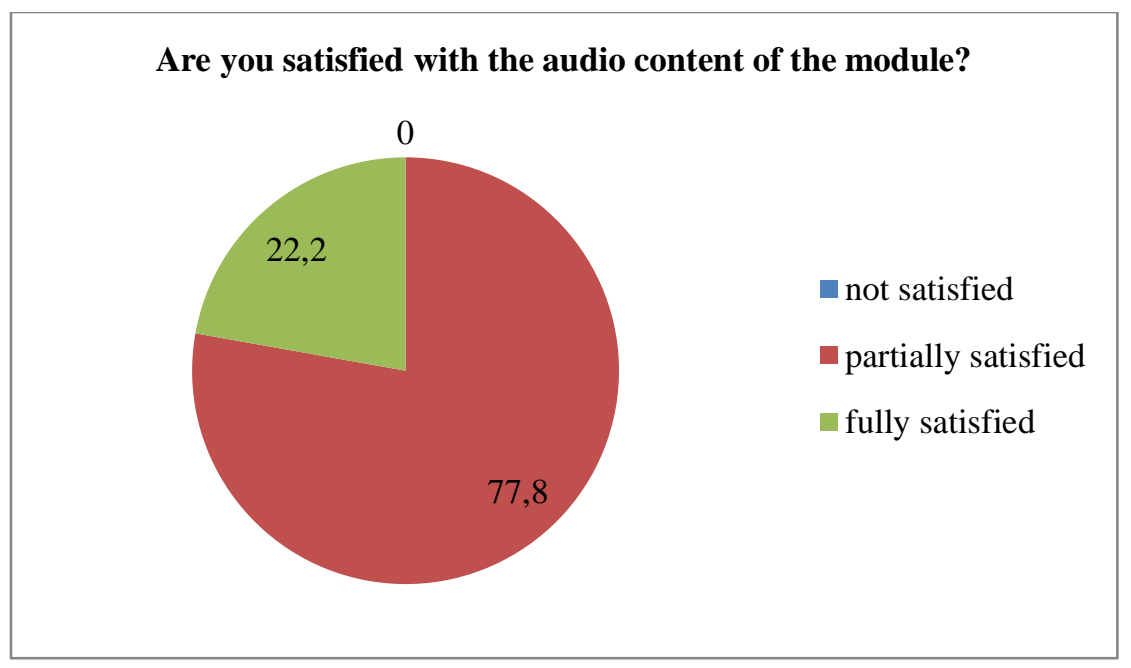

Figure 13. Satisfaction with the audio content (survey responses, \%)

Educators' reports revealed that partial satisfaction with the visuals could be due to the small size of some images. One of the educators recommended making the images of major characters larger and some illustrations more colorful, thus helping the teacher attract and hold children's attention.

The results related to the audio content could be explained not that much by the poor quality of the audio itself but by how this audio was implemented in the design of the online school. No data shows that audio was poorly recorded or text was read inadequately; in fact, audio files were recorded by two professional actors (male and female) on professional quality recording equipment. Moreover, one of the educators praised the tempo of the audio recordings. Partial satisfaction with the audio could be related to educators' complaints about the full version of the story, which in the educators' view was too long and complicated for children. In addition, digital storybooks in their initial versions lacked a pause button. These deficiencies might have affected the evaluation of the audio leaving space for Live Fairytales' developers to work further on the online school's multimodal features.

As Live Fairytales ${ }^{\mathrm{TM}}$ were created for pre-readers, textual input was created mostly for educators (including parents) or for older children who would like to listen and read. Textual input consisted of 1) task instructions; 2) selected task material (e.g., a dialogue); 3) target vocabulary in vocabulary activities (text is written below the image of the object); and 4) feedback for tasks, such as "Correct!", "Good job!" All textual materials went in parallel with relevant audio.

Educators' reports and survey results did not reveal any dissatisfaction with the material presented in the text format, nor there were any positive comments about textual input. Apparently, considering the target audience of the online school, educators did not focus on this feature of the multimodal resource. In fact, most teachers used the term "text" only when referring to the recorded story, i.e., to the audiotext.

Indeed, visual and audio presentation of information best suits the needs of pre-readers. One of the study participants who used Live Farytales ${ }^{\text {TM }}$ with her group of 3-4-year-olds made an important inference in this regard. She wrote,

"Reflecting on the lesson, I can conclude that at the age of 3 or 4 children pay attention to visual information rather than to audio. When in the second fairytale we hear that Domovoj is dressed in a red shirt and blue pants, children think that they have already learned that from the first story, when in fact they only saw Domovoj's image and his clothes were not mentioned in the first story".

This seems to confirm that the formula "a picture worth thousand words" has become an indisputable truth in the visual era making visual learning most common for young learners (Bamford, 2003; Flynt \& Brozo, 2010).

The significance of the visual presentation of information for young learners was also evident in the recommendations for improvement given by the teachers. Most recommendations had to do with visuals rather than audio or textual content. Specifically, teachers recommended making illustrations more varied and colorful, and the characters' looks more modern. Four educators also expressed their wish to have more pictures to illustrate a full version of a story. Adding a picture dictionary was also advised by one of the study participants. A recommendation to add songs was later implemented into the modules of Live Fairytales ${ }^{\mathrm{TM}}$.

\section{Rewards and "learning buddies"}

Live Fairytales ${ }^{\mathrm{TM}}$ includes two design elements that educators found to be conducive to learning as they turned to learn into an engaging activity that creates the situation of play.

The first prominent design element is a reward feature. Each of the 16 modules ends with a child receiving a reward - gems awarded by the dragon $\mathrm{Zmej}$ Gorynych for successful completion of activities. The gems serve as a score calculated for each child, which makes completing a task game-like activity. The educators saw in this feature a tool for engaging children, keeping them on task, and promoting interest 
in the final result.

The second significant design element in Live Fairytales TM are "learning buddies" (Meskill, Sadykova, Anthony, Kayumova, \& Gimaletdinova, 2018). These are characters from the Live Fairytales ${ }^{\mathrm{TM}}$ stories - a girl Masha, a boy Misha, a dragon Zmej Gorynych and a gnome-like man Domovoj. Not only do they serve a role in the plot of each story, but they also perform as learning buddies who address the audience directly, set up a task, model a task, provide task instructions, ask questions, encourage repeating words or phrases, provide feedback or motivate further learning. For instance, in Module 1, Level 1, Masha asks the audience, "What is your name?" After a pause, she adds, "What a beautiful name" thus simulating a real teacher-student dialogue that may happen in a traditional classroom.

Such a form of presenting information and providing feedback seemed to be very well accepted by children and educators alike. Performing the role of a "more knowledgeable other" (Vygotsky, 1978) and at the same time of peers, learning buddies helped to create a friendly and enjoyable environment of play.

\section{DISCUSSION}

The educators that integrated resources of the Russian language online school Live Fairytales ${ }^{\mathrm{TM}}$ reported their high evaluation of the new program. They described lively classroom activities that lasted for about 20 minutes and usually were implemented in a group format with the help of an interactive whiteboard or a single computer and an overhead projector. Active engagement of children was most evident when they were able to manipulate digital objects when completing interactive activities by clicking the mouse or touching the smartboard. Being physically active when performing a language task matches young learners' need to be on the constant move (Dow, 2010; Pica, 2009; Santa, 2009), the concept that has long been applied by those who practice techniques of Total Physical Response (TPR) with young language learners.

The data show that multimodal presentation of the content enabled the teachers to engage children in active listening and interaction with the content, the computer, and the educator. Visual representation of material was reported to be the most valuable and necessary for accompanying audio input, introducing or practicing vocabulary, supporting listening comprehension, and overall motivating very young learners to stay on task. These findings align with previous studies that show that visual input is the leading form of acquiring information for young learners (Felten, 2008; McCrindle, 2013).

Elements of play embedded in the scenario of Live Fairytales $^{\mathrm{TM}}$ supported natural for children developmental environment, in which play is the essential format of learning. Children found peers, play buddies, and at the same time, teachers in the fairytale characters - Masha, Misha, Zmej Gorynych, and
Domovoj. Educators also reported the positive effect of a scoring (reward) system for student engagement. Gamification techniques have been shown to positively affect learning performance of young language learners (Yang, Quadir \& Chen, 2016). Relevant literature speaks for the benefits of simulations and games for acquiring language skills (Peterson, 2009). The active engagement of children into the learning process in a playful format that was reported by educators in this study confirms such views.

While the effect of integrating Live Fairytales ${ }^{\mathrm{TM}}$ on language learning requires additional longitudinal study, the research findings speak for the high evaluation of the program as a tool for developing Russian language skills among children of 3-5 years old. The repetitive and creative use of this digital learning object also implies that early childhood education specialists, such as those who participated in the study, approve of CALL software in their classroom, have technologies and desire to integrate them into their regular curricula and see their students' ability and need to use them for developing language (or other) skills.

\section{CONCLUSIONS}

There is certainly no application that provides one-sizefits-all solution for the needs of language learners (Chen, 2016) and the thesis stating that technologies by themselves may not make (language) learning effective is still true (Golonka, Bowles, Frank, Richardson, \& Freynik, 2014; Gray, 2008; Higgins, Beauchamp \& Miller, 2007). However, we argue that not all educational applications are created equal. Those application developers who collect and consider recommendations of the end users, in our case, these are early childhood education specialists, have much potential to produce a digital resource that will be well accepted, better integrated and longer used. Moreover, open-access state-funded applications may avoid problems commonly found in commercial massproduced software such poorly localized content, including visual contents (Golonka et al., 2014; Reeves \& McKenney, 2013; Shaughnessy, 2003).

This study focused on the way educators make use of one specific language learning application - the online Russian language school for young learners Live Fairytales $^{\mathrm{TM}}$. We were interested to learn how educators integrate its digital resources into regular curricula of early childhood schools - state-funded or private, and what features of this multimodal digital object educators find most valuable for their educational context. Educators' input has served and continues serving the purposes of improving the online school. It is expected that their feedback will be beneficial in building new digital resources for young Russian language learners.

While the study results are limited in generalizability due to the small number of participants and the little scope of focus of inquiry, its insights have helped to fill in gaps in research related to the use of CALL technologies in early childhood education. This 
study extends our understanding of what early childhood educators expect from quality digital resources and how they integrate them into educational programs that support language acquisition of bilingual and multilingual preschool children.

\section{ACKNOWLEDGMENTS}

The reported study was funded by RFBR according to the research project №17-29-09128.

\section{REFERENCES}

Bamford, A. (2003). The visual literacy white paper. Retrieved from http://www.aperture.org/wpcontent/uploads/2013/05/visual-literacy-wp.pdf

Burston, J. (2015). Twenty years of MALL project implementation: A meta-analysis of learning outcomes. ReCALL, 27(1), 4-20. https://doi.org/10.1017/S0958344014000159

Cappellini, M., Lewis, T. \& Rivens Mompean, A. (2017). Learner autonomy and web 2.0. Sheffield: Equinox.

Chen, X. (2016) Evaluating language-learning mobile apps for second-language learners. Journal of Educational Technology Development and Exchange, 9(2), Article 3. https://doi.org/10.18785/jetde.0902.03

Cummins, J. (2008). Technology, literacy, and young second language learners: Designing educational futures. In L. Parker (Ed.) Technology-mediated learning environments for young English learners (pp. 61-98). New York: Lawrence Erlbaum.

Dow, C.B. (2010). Young children and movement. Young Children, 65(2), 30-35.

Felten, P. (2008). Visual literacy. Change: The Magazine of Higher Learning, 40(4), 60-64. https://doi.org/10.3200/chng.40.6.60-64

Flynt, E. S. \& Brozo, W. (2010). Visual literacy and the content classroom: A question of now, not when. The Reading Teacher, 63(6), 526-528. https://doi.org/10.1598/rt.63.6.11

Golonka, E.M., Bowles, A.R., Frank, V.M., Richardson, D.L. \& Freynik, S. (2014). Technologies for foreign language learning: A review of technology types and their effectiveness. Computer Assisted Language Learning, 27(1), 70-105. https://doi.org/10.1080/09588221.2012.700315

Gray, L. (2008). Effective practice with eportfolios. Bristol, UK: JISC Innovation Group.

Grgurović, M., Chapelle, C. \& Shelley, M. (2013). A meta-analysis of effectiveness studies on computer technology-supported language learning. ReCALL, 25(2), 165-198. https://doi.org/10.1017/S0958344013000013

Hampel, R. \& Stickler, U. (2012). The use of videoconferencing to support multimodal interaction in an online language classroom. ReCALL, 24(2), 116-136. https://doi.org/10.1017/s095834401200002x

Higgins, S., Beauchamp, G. \& Miller, D. (2007).
Reviewing the literature on interactive whiteboards. Learning, Media and Technology, 32, 213-225. doi: 10.1080/17439880701511040

Hunter, C. (2015). Understanding and managing children's behaviour through group work ages 5 7. London: Routledge.

Hunter, C. (2016). Understanding and managing children's behaviour through group work ages 35. London: Routledge.

Kazanci, Z. \& Okan, Z. (2009). Evaluating English language teaching software for kids: Education or entertainment or both? Turkish Online Journal of Educational Technology, 8(3), 30-38.

Khajavy, G., MacIntyre, P. \& Barabadi, E. (2018). Role of the emotions and classroom environment in willingness to communicate: Applying doubly latent multilevel analysis in second language acquisition research. Studies in Second Language Acquisition, 40(3), 605-624. https://doi.org/10.1017/s0272263117000304

Liu, C., Wang, P. \& Tai, S. (2016). An analysis of student engagement patterns in language learning facilitated by Web 2.0 technologies. ReCALL, 28(2), 104-122. https://doi.org/10.1017/s095834401600001x

Lohe, V. \& Elsner, D. (2014). Developing language awareness in primary school children with multilingual virtual talking books: First results of the pilot study. International Journal of ComputerAssisted Language Learning and Teaching (IJCALLT), 4(4), 29-45. https://doi.org/10.4018/ijcallt.2014100103

McCrindle, M. (2013). Generation Z defined: Global, visual, digital. Retrieved [Blog post] from http://www.mccrindle.com.au/the-mccrindle-blog/ generation_z_defined_global_visual_digital

Meskill, C. (2002). Teaching and learning in real time: Media, technology, and language acquisition. Houston, TX: Athelstan.

Meskill, C. (2007). English language learners and technology: Transforming teaching and learning. In L. Parker (Ed.), Technology-based learning environments for young English learners: In and out of school connections (pp. 253-261). New York: Taylor and Francis.

Meskill, C. \& Mossop, J. (2000). Technologies use with learners of English as a second language in New York State. Journal of Educational Computing Research, 22(3), 265-284. https://doi.org/10.2190/9G4W-V1JE-XY69-L1ME

Meskill, C., Mossop, J. \& Bates, R. (1999). Bilingualism, cognitive flexibility, and electronic texts. Bilingual Research Journal, 23 (2\&3),. 113124. https://doi.org/10.1080/15235882.1999.10668689

Meskill, C., Sadykova, G., Anthony, N., Kayumova, A., Gimaletdinova, G., (2018). Online bilingual maintenance for young Russian learners through digital fairy tales. Paper Presented at the 2018 Annual Meeting of the American Educational 
Research Association. Retrieved from the AERA Online Paper Repository.

http://www.aera.net/Publications/Online-PaperRepository/AERA-Online-Paper-

Repository/Owner/256539

Meyer, B. (2013). Game-based language learning for pre-school children: A design perspective. The Electronic Journal of e-Learning, 11 (1), 39-48.

OfCom (2017). Children and parents: Media use and attitudes report 2017. Retrieved from https://www.ofcom.org.uk/_data/assets/pdf_file/0 020/108182/children-parents-media-use-attitudes2017.pdf

Peterson, M. (2009). Computerized games and simulations in computer-assisted language learning: A meta-analysis of research. Simulation \& Gaming, 41(1), 72-93. https://doi.org/10.1177/1046878109355684

Pica, R. (2009). Physical fitness and the early childhood curriculum. Early Childhood Education, 43, 198203.

Reeves, T. C. \& McKenney, S. (2013). Computerassisted language learning and design-based research: Increased complexity for sure, enhanced impact perhaps. In J. C. Rodriguez, \& C. PardoBallester (Eds.), Design-based Research in CALL (pp. 9-21). San Marcos, Texas: CALICO

Rogers, B. \& McPherson, E. (2014) Behaviour management with young children: crucial first steps with children 3-7 years (2nd ed.). Los Angeles: SAGE.

Sadykova, G., Gimaletdinova, G., Khalitova, L. \& Kayumova, A. (2016). Integrating mobile technologies into very young second language learners' curriculum. In S. Papadima-Sophocleous, L. Bradley, \& S. Thouësny (Eds.), CALL communities and culture - short papers from EUROCALL 2016 (pp. 408-412), Researchpublishing.net, doi: 10.14705/rpnet.2016.eurocall2016.597

Sadykova, G., Kayumova, A., Khalitova, L. \& Gimaletdinova, G. (2017). Designing CALL technologies for very young language learners: Exploring parents', educators' and designers' views. [Abstract]. EUROCALL 2017 Abstract Book, 87.

Sankey, M., Birch, D. \& Gardiner, M. (2010). Engaging students through multimodal learning environments: The journey continues. In C.H. Steel, M.J. Kepell, P. Gerbic \& S. Housego (Eds.), Curriculum, technology \& transformation for an unknown future. Proceedings of the ascilite Sydney 2010 (pp. 852-863). Retrieved from http://research.usc.edu.au/vital/access/manager/Re pository/usc:7026

Santa, A. (2009). The playground as classroom. Early Childhood Education, 33, 154-155.

Schwienhorst, K. (2008). Learner autonomy and CALL environments. New York, NY: Routledge.

Segers, E. \& Verhoeven, L. (2003). Effects of vocabulary training by computer in kindergarten. Journal of Computer Assisted Learning, 19(4), 557-566. https://doi.org/10.1046/j.02664909.2003.00058.x

Segers, E. \& Verhoeven, L. (2005). Long-term effects of computer training of phonological awareness in kindergarten. Journal of Computer Assisted Learning, 21(1), 17-27. https://doi.org/10.1111/j.1365-2729.2005.00107.x

Shaughnessy, M. (2003) CALL, commercialism and culture: Inherent software design conflicts and their results. ReCALL, 15 (2), 251-268. https://doi.org/10.1017/s0958344003000922

Sylvén, L.K. \& Sundqvist, P. (2012). Gaming as extramural English L2 learning and L2 proficiency among young learners. ReCALL, 24(3), 302-321. https://doi.org/10.1017/s095834401200016x

Vygotsky, L. S. (1978). Mind in society: The development of higher psychological processes. Cambridge, MA: Harvard University Press.

Yang, J. C., Quadir, B. \& Chen N-S. (2016). Effects of the badge mechanism on self-efficacy and learning performance in a game-based English learning environment. Journal of Educational Computing Research, 54(3), 371-394. https://doi.org/10.1177/0735633115620433

Young, D. J. (1991). Creating a low-anxiety classroom environment: What does language anxiety research suggest? The Modern Language Journal, 75, 426437. https://doi.org/10.1111/j.15404781.1991.tb05378.x

Zhivye skazki [Live Fairytales]. (2017). Retrieved from https://skazki.pushkininstitute.ru/ 